\title{
The Russian Brassicaceae collection - from N.I. Vavilov and E.N. Sinskaya till nowadays
}

\author{
A.M. Artemyeva $\otimes$, A.G. Dubovskaya, N.G. Kon'kova \\ Federal Research Center the N.I. Vavilov All-Russian Institute of Plant Genetic Resources (VIR), St. Petersburg, Russia \\ هe-mail: akme11@yandex.ru
}

This article presents the history of the formation of the Russian state Brassicaceae collection maintained at the N.I. Vavilov All-Russian Institute of Plant Genetic Resources (VIR). Nowadays this one of the world's richest collections encompasses more than 10,750 accessions of different status from 32 species and 11 genera: vegetable, fodder, oilseed, spicy, ornamental crops and continues to grow through collecting missions and exchange of material. The first intraspecific botanical and agrobiological ecologo-geographical divisions of many crops - cole, turnip, radish, small radish, Swede - were performed by E.N. Sinskaya and T.V. Lizgunova over years of research. These unique works have been continued by M.A. Shebalina and L.V. Sazonova: the cultivar types of Chinese cabbage and pakchoi have been determined; the development of the classifications of white cabbage, broccoli, small radish, turnip is being continued. The objective laws of variability of valuable biochemical traits are presented; a comparative analysis of nutritive and biologically active substances, primarily secondary metabolites, allowed us to determine specific biochemical compounds: those common for the related species Brassica oleracea and B. rapa but occurring in them at different frequencies and those unique for species, subspecies and separate cultivar types; this is the beginning of taxonomic studies. With phytopathological studies, the common diseases of Brassicas in the northwestern part of Russia were determined, and the level of their distribution and development depending on the crop was shown. Genetic studies of the Brassicaceae collections at VIR include DNA analysis to search for duplicates in the collections, to compare original seeds and the seeds after reproduction and to assess the authenticity of saved accessions, to assess biodiversity, including that of new material from collecting missions, to develop phylogenetic studies. Chromosome loci controlling flowering time, morphological and biochemical traits were determined by QTL analysis and association mapping, the molecular markers found are used for screening the collection and breeding material. The sources and donors of traits valuable for modern breeding directions have been found for use in various breeding programs.

Key words: Brassicaceae collection; formation; complex evaluation; biochemical and immunological studies; QTL analysis; association mapping.

For citation: Artemyeva A.M., Dubovskaya A.G., Kon'kova N.G. The Russian Brassicaceae collection - from N.I. Vavilov and E.N. Sinskaya till nowadays. Vavilovskii Zhurnal Genetiki i Selektsii =Vavilov Journal of Genetics and Breeding. 2019; 23(6):787-794. DOI 10.18699/VJ19.553

\section{Российская коллекция Brassicaceae: от Н.И. Вавилова и Е.Н. Синской до наших дней}

\author{
А.М. Артемьева 凶, А.Г. Аубовская, Н.Г. Конькова
}

Федеральный исследовательский центр Всероссийский институт генетических ресурсов растений им. Н.И. Вавилова (ВИР), Санкт-Петербург, Россия هe-mail: akme11@yandex.ru

Представлена история создания российской государственной коллекции семейства Капустные (Brassicaceae), сохраняемой в ФИЦ Всероссийский институт генетических ресурсов растений им. Н.И. Вавилова (ВИР). В настоящее время это одна из самых обширных в мире коллекций, включающая более 10750 образцов различного статуса, принадлежащих 11 родам и 32 видам овощных, кормовых, масличных, пряно-вкусовых и декоративных культур. Коллекция пополняется за счет регулярных экспедиционных сборов и обмена материалом. Первые внутривидовые ботанические и агробиологические эколого-географические классификации многих культур капусты, репы, редьки, редиса, брюквы - были сделаны Е.Н. Синской и Т.В. Лизгуновой в процессе многолетнего изучения. Затем эти уникальные работы продолжили М.А. Шебалина и Л.В. Сазонова. Исследования проводятся в ВИР и сегодня: выделены сортотипы пекинской и китайской капусты, в стадии доработки находится агробиологическая классификация белокочанной капусты, брокколи, редиса и репы. В статье приведены результаты изучения закономерностей изменчивости ценных биохимических признаков. Так, сравнительный анализ накопления питательных и биологически активных соединений, прежде всего вторичных метаболитов, позволил установить для родственных видов капуста и репа общие компоненты биохимического состава, встречающиеся с различной частотой и уникальные у видов, подвидов и отдельных сортотипов, что является подходом к хемосистематике. Благодаря фитопатологическим исследованиям определены общие заболевания капустных культур на Северо-Западе России, показана степень распространения и развития болезней в зависимости от культуры. Генетические исследования коллекций Brassicaceae в ВИР включают ДНК-анализ для поиска дублетов, 


\begin{abstract}
сравнения оригинальных семян с репродукциями и установления аутентичности сохраняемых в генном банке образцов, оценки биоразнообразия, в том числе биоразнообразия нового экспедиционного материала, проведения филогенетических исследований. С помощью QTL-анализа и ассоциативного картирования капустных культур были установлены хромосомные локусы, контролирующие время перехода к цветению, морфологические и биохимические признаки, при этом найденные молекулярные маркеры используют для скрининга коллекционного и селекционного материала. Выделены источники и доноры ценных признаков по новым направлениям селекции для различных селекционных программ.

Ключевые слова: коллекция Brassicaceae; создание; комплексное изучение; биохимические и иммунологические исследования; QTL-анализ; ассоциативное картирование.
\end{abstract}

\section{VIR Brassicaceae collections formation and modern condition}

Family Brassicaceae Burnett is one of the largest, young, fast evolved family in plant kingdom with approximately 338 genera and 3709 species (Warwick, Hall, 2009), encompassing wild and many cultivated oilseed, vegetable, spicy, ornamental species that included in the basis of worldwide economy. N.I. Vavilov, famous botanist, phytopathologist and geographer, began to be Bureau of Applied Botany - future VIR - Director in 1920 and he had invited to VIR many scientists, among them E.N. Sinskaya, who worked with fodder, oilseed and rooted brassicas, T.V. Lizgunova, curator of vegetable cole collections. E.N. Sinskaya continued the Vavilov determination of centers of origin and biodiversity of cultural crops and their wild relatives (Vavilov, 1926), prepared a significant work "Historical Geography of Cultivated Flora" (1969).

The formation of VIR Brassicaceae collection had begun in 1923 after N.I. Vavilov visit West-European countries, USA and Canada (1921-1922) and from All-Russian agricultural exhibitions. In 1926 VIR scientists started to study 450 acc. of white cabbage and cauliflower, 150 turnip acc., 90 radish acc., 180 mustard acc.

1500 accessions of vegetable brassicas and 450 oilseed accessions were collected by N.I. Vavilov himself and his colleagues till 1940: for instance, in expeditions 1925-1929 231 acc. were collected by N.I. Vavilov in the countries of Mediterranean basin, Ethiopia, China, Korea, Japan, Taiwan, 360 acc. were collected by P.M. Zhukovskiy in Minor Asia and Syria, 90 acc. by V.V. Markovich in India, China, Japan, 241 acc. by E.N. Sinskaya in Japan. Collection had grown by exchange of valuable material with different Institutes and companies in Western Europe and North America. But only $20 \%$ brassicas accessions were saved from this time during the 2nd World War. From 1941 till 1945 the collections were stored in Leningrad; a small part of valuable vegetable brassicas accessions was evacuated to Ural.

Resumption of VIR brassicas collection started from 1946, when loss material was collected from the same locations as in N.I. Vavilov time and bought from the same breeding companies like Vilmorin (France), Sluis en Groot, NickersonZwaan B.V. (Netherlands), Dippe, Lembke (Germany), etc. The first round of new reproduction and new characterization and evaluation trials has begun from 1946. From 1950 VIR collections enriched very intensively. Local resources from ex former USSR, China, India, Japan, Syria, Turkey, and Australia were collected very full.

Nowadays the Russian state worldwide Brassicaceae collection keeping in N.I. Vavilov All-Russian Research Institute of Plant Genetic Resources (VIR) is one of the largest in the world; the largest Indian collection includes 11238 accessions, other large Brassicaceae collections are stored in United Kingdom (5329 acc.), Germany (4303 acc.), USA (4993 acc.), China (5500 acc.) and Japan (1831 acc.). In European data base 25901 brassicas are located. VIR Brassicaceae collection consists of 10759 accessions of 32 species belonging to 11 genera: vegetable, fodder, oilseed, spicy, ornamental crops. Among them it includes large collections of traditional crops: cole crops Brassica oleracea L. - 2420 accessions, Asian and European leafy and rooted crops Brassica rapa L. more than 1500 acc., radish and small radish Raphanus sativus L. - 2390 acc., rapeseed Brassica napus L. oleifera Metzg. - 1300 acc., Indian mustard Brassica juncea (L.) Czern. - 1260 acc., and also old quite rare crops but becoming popular now in Russia again Swede Brassica napus L. rapifera Metzg., water cress Lepidium L. sp., salad rocket Eruca sativa L., turnip rape Brassica rapa L. oleifera Metzg., white mustard Sinapis alba L., false flax Camelina L. sp. and others.

According N.I. Vavilov worldwide collection should reflect natural biodiversity of cultural crops and their wild relatives and also general genepool of modern breeding achievements. The VIR collection includes the accessions of different status: landraces (30\%), old and advanced breeding cultivars (58\%), inbred and double haploid lines, hybrid populations, mapping populations (12\%). VIR Brassicaceae collections compose around $80 \%$ unique accessions.

Nowadays big attention takes to collect local types and morphotypes with high level of resistance to biotic and abiotic stresses, valuable biochemical composition, decorative characters; introduction of the new for Russia crops and cultivar types; collection of the best world achievements on the newest breeding directions; addition of the new genetic material. Very important unique local accessions of white cabbage, turnip and radish have been collected during last five years in South part of Russia, Altay, Far East, and also in Armenia, Azerbaijan, Tajikistan, China. Earliest accessions of cauliflower, broccoli and kohlrabi have been received from the Dutch and Japanese breeding companies, turnip and leafy Asian crops accessions from Chinese Institutions and a company from USA, vegetable types of Indian mustard - from Chinese Genbank.

In VIR the procedures of storage, regeneration, multiplication, distribution of accessions to users have been managed as in modern Genebank, including safety duplication of large part of collections in two locations: in St. Petersburg in the freezers under $-10{ }^{\circ} \mathrm{C}$ and at Kuban station (Southern part of Russia) underground under $+4{ }^{\circ} \mathrm{C}$. Most accessions from the base collections stored in St. Petersburg under $+4{ }^{\circ} \mathrm{C}$ for short-term storage. Most brassicas accessions have coefficient of safety duplication 2.5-2.8. $5 \%$ brassicas accessions have been stored in Svalbard Global Storage. VIR Brassicaceae 
crops and wild relatives Herbarium includes 1673 accessions of 105 species, 16 genera; weed Brassicaceae Herbarium includes representatives of 56 genera.

\section{The main goals of PGR evaluation at VIR}

\section{Intraspecific division on the base of ecologo-geographical evaluation}

The VIR evaluation strength is complete phenotyping of all accessions in the different ecologo-geographical zones of Russia according the same methodic during three years. The VIR evaluation data bases according original VIR descriptor include 47-55 morphological and phenological characters for vegetable crops, 18-23 characters for oilseeds, and separate immunological, physiological, and biochemical data bases too (Methodics, 1988, 1989).

As results of characterization and evaluation of brassicas collections for many years and phylogenetic studies VIR scientists created intraspecific ecologo-geographical classifications of cole, turnip, Swede, radish, Indian mustard and other mustard crops, prepared descriptors for brassicas and studied variability of many traits (Sinskaya, 1928, 1939, 1969; Lizgunova, 1959, 1965, 1984; Shebalina, 1974; Shebalina, Sazonova, 1985). They divided each cultivated species on subspecies, convarieties, varieties, botanical forms, agrobiological eco-geographical groups and cultivar types. This work is being continued in VIR nowadays. Need to note that the taxonomy and phylogeny of Brassicaceae is under discussion and determination in the world till now despite of great efforts to delimitate tribes and species. Many types of molecular markers have been carried out including different DNA regions as barcodes for taxonomic identification where ITS were the best (Warwick, Hall, 2009; Warwick et al., 2010).

All modern classifications of crops including molecular genetic works are finishing on botanical varieties and forms and modern researchers use agro-biological classifications developing by VIR scientists (Bradshaw, 2010; Wang, Kole, 2015). For example, Brassica rapa L. contains a number of crops with great economic importance of different use. After C. Linneus, F.I. Ruprecht, and L. Bailey E.N. Sinskaya described 10 separate species: B. campestris L., B. chinensis L., $B$. chinoleifera Viehoever, B. dubiosa Bailey, B. glauca Wittm., B. narinosa Bailey, B. nipposinica Bailey, B. pekinensis Rupr., B. rapa L., B. trilocularis Hook. et Thompson (Sinskaya, 1969). Modern classifications determined all these crops as subspecies and varieties into Brassica rapa species (Hanelt, 1986; Gladis, Hammer, 1992; Specht, Diederichsen, 2001), but final common intraspecific classification does not exist till now.

According to E.N. Sinskaya, turnip and turnip rape had a wild progenitor; it was form, closely related to cultivated winter turnip rape, with inclination for enlarged root formation. European forms were domesticated in Minor Asia, and Asian - in Afghanistan and North India. The oleiferous forms also could be domesticated separately: in Mediterranean center of origin and in Central Asia, Afghanistan and North-East India. In India three ecotypes of oleiferous $B$. rapa exist: yellow sarson, toria and the oldest brown sarson was evolved in North-East India from original initial plant of B. rapa (Sinskaya, 1928). Nowadays B. rapa is considered originated in two independent centers of origin - Mediterranean area as the primary center for oleiferous/rooted forms and Central Asia for turnip forms, then turnip distributed to different directions where different types were developed. In India the primitive types developed oilseed forms, in China - oilseed and leafy forms (Wang, Kole, 2015).

E.N. Sinskaya divided turnip B. rapa L. on two species B. rapoasiatica Sinsk. and B. rapoeuropea Sinsk., in the first she included oldest primitive Afghan form and originated from it Indian, Middle Asian, Japanese turnips, in the second - primitive Minor Asian turnips and originated from them European turnips and determined 9 eco-geographical groups: (1) Teltov; (2) Western European; (3) Russian yellow flash; (4) Intermediate type between Russian and Asian; (5) Minor Asian with distinct leaves; (6) Afghanis; (7) Japanese with entire leaves; (8) European with entire leaves; (9) Chinese with entire leaves without hairiness. Then M.A. Shebalina (1974) divided turnip on 5 varieties: European, Minor Asian, Iraqi, Central Asian, and Japanese; European variety divided on 25 cultivar types, but according her meaning, these cultivar types do not include all biodiversity of turnip cultivars. Now on need to divide the last M.A. Shebalina varieties on morpho-physiological cultivar groups.

E.N. Sinskaya, then M.A. Shebalina and L.V. Sazonova (1985) divided the radish Raphanus sativus L. on 3 subspecies: European, Chinese, Japanese, and each subspecies on varieties, correspondingly 6,5 and 2 . Small radish accessions have been divided on European and Chinese convarieties, including 4 and 2 varieties, generally corresponded of root colour, and 14 cultivar types. Follow by modern evaluation in VIR small radish collection was divided on 6 groups on the base of morphological characters of root, leaf rosette, phenological traits, resistance to bolting, etc., and DNA data (Artemyeva et al., 2017).

Accordind to E.N. Sinskaya opinion, rapeseed, turnip rape, black and charlock mustard are authentically unknown in a nature as wild forms. They seem to be originated from Mediterranean region, and probably had independent history of domestication at several spots. As results of investigation of the British oilseed rape samples, E.N. Sinskaya concluded that oilseed rape putatively amphidiploid, originated from the cross of ancient Atlantic form of wild kale with turnip rape (Sinskaya, 1960, 1969). According to De Candolle opinion, rapeseed has entered to Russia from Ukraine territory. This theory can be proved by a fact, that $20 \%$ of the rapeseed landraces and old cultivars were collected at Ukraine (among accessions, collected before 1982).

T.V. Lizgunova believed the modern recognized cultural varieties of cole crops B. oleracea (Gómez-Campo, Prakash, 1999) by separate species in a composition of $B$. aggr. oleracea (L.) Lizg. (Lizgunova, 1965, 1984). She divided cole crops collections on cultivar types. Nowadays origin of some Russian and European white cabbage types - Savinskaya, Schweinfurter, Dobrovodske by hybridization of European and oriental types have been proposed; Italian sprouting broccoli have been divided on three types according the primer and second centers of origin Italy, USA and Japan (Artemyeva et al., 2017).

VIR Chinese cabbage collection intravariety classification has been done, 14 cultivar types have been determined: 
into $B$. rapa pekinensis dissoluta $\mathrm{Li}$ - type Dunganskaya, var. infarcta Li - types Shantung, Siao, Nagasaki, Chirimen, var. laxa Tsen et Lee - Chosen, Kashin, var. cephalata Tsen et Lee-Chee-Foo (Wong-Bok) (subtypes Chee-Foo and Matsushima), Hotoren, Kaga, Aichi (subtypes Aichi and Nozaki), var. cephalata f. cylindrica Li - Granat (Michihli) (subtypes Granat and Khe-tou), Da-zin-kou, var. cephalata f. depressa Li Kensin. According large biodiversity into Granat cultivar type possibly to determine Khe-tou subtype as separate type. $B$. rapa chinensis collection has been divided on 5 cultivar types Taisai, Piorbai, Syusman, Yu Tsai, Lei choi (Artemyeva, 2001, 2004; Artemyeva, Abremskaya, 2017).

VIR brassicas collections have been structured. Genetic collection includes accessions with identified genes: for example, rapeseed genetic collection includes lines with identified genes controlled morphological traits, fatty acids composition, resistance to Fusarium, CMS polima system; pak-choi genetic collection includes double haploid lines with identified and localized chromosome loci determined many morphological, biochemical and immunological characters.

Trait collections present a system of intraspecific variability of studied traits, determination of the sources and creation of donors of these traits. Amplitude of natural variation of productivity, earliness, resistance to biotic and abiotic stresses, features of biochemical composition in brassicas is enormous. The limits of variation of quality traits in each crop have been determined, and accessions divided on statistically distinct groups. For instance pak-choi collection is divided for the quantity traits of plant size (plant diameter, height, lamina and petiole lenght and width) and productivity on 6-9 groups. The trait collections have been developed for all characters of breeding interest: vegetation period, weight, productivity, size, shape, colour of productive organ, habitus of leaf rosette, leaf morphological characters, resistance to diseases and insects, edaphic factors, cold, frost and heat, valuable nutritive and biologically active compounds, dwarfism. The agrobiological models of the future cultivars for different breeding directions and for different climatic conditions have been created in VIR for all brassicas crops.

\section{Biochemical studies}

Food nutrition is becoming one of the most important factors in the choice of products in modern conditions. Brassica crops are characterized by low caloric value; contain high quality protein, carbohydrates, fiber, minerals, and biologically active compounds: vitamins, enzymes, pigments, secondary metabolites. In humans, the last mentioned reduce risk of chronic diseases development having anticarcinogenic, antioxidant, antibacterial and antiviral effects, stimulate the immune system and reduce inflammation. Brassicas also prevent from development of cardiovascular diseases and illnesses associated with ageing. These arguments enable to recommend increased consumption of brassicas. In the number of researches analysis of bioactive compounds accumulation, the mechanisms of their action in Brassicaceae family and the biotechnological approaches enriching the content of antioxidant compounds in the plants have being considered (Raiola et al., 2018).

In VIR classical biochemical analysis of brassicas accessions, determination of resources of valuable compounds for breeding programs has been continued from 1936. 50-90\% accessions of collections from all cultivars types were evaluated for dry matter, sugars, vitamin $\mathrm{C}$, organic acids, protein, carotene, chlorophylls, total glucosinolates and nitrates content. The cultivars types of all crops display a wide diversity of characters and among them the sources of nutritive and bioactive substances were revealed.

Nowadays objective laws of biochemical compounds accumulation by vegetable brassicas and their cultivar types have been found in VIR by metabolome analysis and chemosystematics studies using gas and liquid chromatography (GLC). Biochemical analysis of 180 accessions of cole crops, 320 accessions of $B$. rapa crops, including core collection, mostly leafy and rooted crops, 70 accessions of radish, 90 accessions of small radish and 10 accessions of vegetable Indian mustard have been studied, some of accessions both in the field and in greenhouse conditions. The large potential of variability of nutritive and bioactive substances between and within Brassicaceae species, subspecies, varieties, cultivar types was found.

Comparative biochemical analysis with chemotaxonomic issue for B. oleracea (white cabbage, tronchuda, cauliflower) and $B$. rapa leafy crops (Chinese cabbage, pak-choi, tatsoi, tsoisum, wutacai, mizuna, leafy turnip, broccoletto, oilseeds) has been done. For instance, in B. rapa crops 16 sugars $(84 \%$ monosugars) have been found, natural variation: $0.02-5.56 \%$ (average $0.83 \%$ per fresh matter), in B. oleracea crops 15 sugars. The common sugars for two relative species were glucose, sorbose, mannose, galactose, fructose, sucrose; highest amount of glucose and sucrose have been observed. In some Chinese cabbage accessions tetra saccharide stachyose was found. Total 16 and 17 alcohols have been found in B. rapa and B. oleracea correspondingly, among them 8 biologically active. The common alcohol for two species was inositol; glycerol and sitosterol have been determined with high frequency. Variability of free amino acids content was significant for studied accessions: $8.5-716 \mathrm{mg} / 100 \mathrm{~g}$ (average $143 \mathrm{mg} / 100 \mathrm{~g}$ ). Among 29 founded amino acids the common were glutamine, glutamine acid, asparagine, asparagine acid, serine, oxyproline - their content is highest, alanine and indispensable amino acids valine and threonine have been found common too. Other indispensable amino acids have been determined to be present with different frequency among crops, but mostly in headed Chinese cabbage and white cabbage.

In a study 35 and 32 organic acids have been found in two Brassica species, from that 23 and 18 acids were found in more than $15 \%$ accessions; 9 organic acids were common, among them highest content of maleic, ascorbic, phosphoric acids have been noted. B. rapa accessions had a lot of fumaric acid. Some organic acids are biologically active, for instance pipecolic, abietic, ursolic acids. Pak-choi and leafy turnip were the richest by organic acids, although Chinese cabbage had the most content of phosphoric acid, broccoletto - caffeic acid. Among organic acids 13 phenol compounds have been determined; variability of them is from trace to $262 \mathrm{mg} / 100 \mathrm{~g}$ (average $44 \mathrm{mg} / 100 \mathrm{~g}$ ). The common phenol compounds for Brassica is quinic acid, for $B$. rapa - sinapic and ferulic acids too. Abietic and caffeic acids and tocopherol were found in all $B$. rapa crops except Chinese cabbage, chlorogenic acid presented in pak-choi and tatsoi, hydroxycinnamic acid - in pak-choi only. Significant positive correlations between con- 
tent of amino acids alanine and tyrosine and phenol compounds nicotinic, sinapic, benzoic acids and tocopherol have been found. Among founded free fatty acids -17 in B. rapa and 12 in B. oleracea - common for Brassica was palmitic acid, with high frequency linoleic and linolenic acids have been determined, common for B. rapa crops - stearic and oleic acids.

Generally $B$. rapa crops composed significantly less nutritive compounds sugars than $B$. oleracea crops, but more or significantly more of all studied biologically active compounds. Valuable for human nutrition Brassicaceae accessions with high level of dry matter, sugars, ascorbic acid, biologically active alcohols, indispensable amino acids, phenol compounds, fatty acids have been found. Among B. rapa crops the most useful for human nutrition are tatsoi, pak-choi (cultivar types Leichoi and Yu Tsai), leafy turnip (hiroshimana type), late types of broccoletto; among cole crops - Russian and Dutch types of white cabbage, early types of cauliflower, tronchuda; among small radish - extra early red round and Chinese late types, among turnip - old Russian types Petrovskaya and Grobovskaya and French dry type, among Swede - Scandinavian types.

More than 700 accessions of rapeseed and turnip rape had been studied on oil content and fatty acids composition. Agricultural production is one of the main diesel fuel consumers. Emissions of internal combustion engines are one of the main causes of environmental pollution, so recently the requirements for the diesel fuel quality have become more stringent. In addition, the design of diesel engines is improving continuously which also requires the use of better quality diesel fuel. Biodiesel is synthesized from renewable raw materials; the sulfur content is lower than in diesel fuel and also diesel fuel has a higher cetane number and flash point. The range of raw materials for biodiesel production is constantly expanding. However, non-erucic rapeseed oil is a food product and its use for technical purposes is impractical. There are high-erucic technical varieties of rapeseed, but their crops are limited as spatial isolation from food rapeseed is required to avoid plant pollination. The cultivation of this crop requires certain costs due to the repeated use of insecticides against numerous insect pests during the growing season. In connection with the above, a comprehensive study of non-traditional Brassicaceae family oil crops less affected by pests was undertaken (Nagornov et al., 2017; Sainger et al., 2017). These crops include Camelina sativa (L.) Crantz, Crambe abyssinica Hochst. and Eruca sativa Mill. Studies conducted in VIR jointly with All-Russian Scientific Research Institute for the Use of Machinery and Oil Products in Agriculture have shown that the use of camelina, crambe and eruca raw material for biodiesel production is cheaper and environmentally friendlier compared to rapeseed. Biodiesel produced from these crops oils was obtained; their physical and chemical characteristics were established. It is established that biodiesel fuel created on the basis of these crops matches the requirements for this type of product (Romantsova et al., 2012).

Oilseed crops of family Brassicaceae as biodiesel resources were considered in a special study. 1038 accessions of rapeseed (Brassica napus ssp. oleifera Metzg.), 60 accessions of $C$. sativa L., 45 accessions of $C$. abyssinica Hochst. and 60 accessions of $E$. sativa Mill. from VIR collection were analyzed. Natural contents of erucic acid varied in rapeseed from 10 up to $61 \%$, but in food varieties there is less than $1 \%$ of erucic acid. In camelina content of erucic acid varied from 2.6 up to $7.5 \%$ (Ghamkhar et al., 2010). In crambe it varied from 54 up to $66 \%$, in eruca - from 42 up to $55 \%$. It is determined, that with the increase of erucic acid level the content of the saturated fatty acids (palmitic and stearic) decreases that is important for the increasing of biodiesel resistance to congelation. As a result the initial material for spring and winter rapeseed breeding with more than $40 \%$ of erucic acid was described.

\section{Immunological studies}

Brassicaceae plants have been infected by bacterial, viral, many fungal diseases, more harmful in the central and Southern part of Russia on industrial growing. Resistance to diseases has been studied in VIR generally in the field natural conditions in St. Petersburg area, North-west Russia, to clubroot and black rot in artificial conditions. More than 1700 vegetable brassicas accessions have been tested, partly jointly with All-Russian Research Institute of Plant Protection, on level of distribution and degree of resistance to leaf spot (Alternaria brassicae (Berk.) Sacc. and A. brassicicola (Schwein.) Wiltshire), clubroot (Plasmodiophora brassicae Woron.), black rot and leaf spot (Xanthomonas sp.), downy mildew (Peronospora parasitica (brassicae) (Pers.) Fr.), powdery mildew (Erysiphe communis f. brassicae Hammarl.), wilt (Fusarium oxysporum Schlecht. emend. Snyder \& Hansen) (Gasich et al., 2013).

The most distributed pathogens in North-west area belong to Alternaria species; $80-100 \%$ of white cabbage, cauliflower and Chinese cabbage accessions and $40-100 \%$ of red cabbage accessions depending of year were susceptible to this pathogen, with low and middle degree of susceptibility $0.25-2.5$. Several accessions of cauliflower from Russia, Australia, Japan are high tolerant to Alternaria leaf spot. The highest level of resistance showed the accessions with red colour of leaves and head: red cabbage, pak-choi, tatsoi, mizuna: 0.0-0.35.

Under artificial conditions in our studies tatsoi Bitaminna (k-213, Japan) was resistant to clubroot. High level of resistance to this pathogen has been shown by leafy turnip Kurona (k-264, Japan), local Chinese cabbage Shantai (k-68, China), turnip Mommersteegis Clubroot Resistant (k-1119, Sweden), Red Top Globe (k-1226, Denmark), Tartonda (Tetraploid) (k-1294, Germany). We can confirm that the sources of resistance have been originated from areas with strong development of clubroot.

Different species of genera Xanthomonas with several pathotypes cause diseases with different symptoms - black rot and leaf spot. Plant breeding on resistance is difficult because of less number of resistant sources and many races of the pathogen. Races 2 and 4 of Xanthomonas campestris Pam. (Dow.) are the most widely distributed, including Russia, Europe and Japan. High level of tolerance to these races was found in different varieties of $B$. oleracea $\mathrm{L}$.

Susceptibility to downy mildew is common in Brassica crops: $10-50 \%$ accessions of cole crops and Chinese cabbage were susceptible with degree $0.5-1.8$, these meanings were less in red cabbage and pakchoi accessions. Several resistant to downy mildew accessions of cauliflower from Italy and Japan were revealed. Opposite powdery mildew is rare pathogen 
in North-west part of Russia: distribution was 0-20\% with degree $0.2-1.0$ on white cabbage, cauliflower and Chinese cabbage accessions, strong susceptibility has been noted on some kale accessions from Scandinavian countries and France. Wilt is also rare pathogen in this area, its development has been determined on several white cabbage accessions.

Resistance to the most harmful insect for brassicas cabbage root fly (Delia radicum) in Scandinavian resources of kale, turnip, Swede has been found, resistance to crucifer flea beetle (Phyllotreta cruciferae) - in Swede genotypes, mostly from Russia and central Europe, resistance to cabbage scoop (Mamestra brassicae) and cabbage butterfly (Pieris brassicae) - in kale and several local white cabbage accessions from Southern Russia and Balkan countries, that correlates with high level of glucosinolates content. Resistant sources in VIR collections are useful for the new breeding programs.

\section{Genetic studies}

The $B$. rapa whole genome sequence was a start of new era in Brassicaceae researches (Wang et al., 2011), then B. oleracea genome sequence (Liu et al., 2014; Parkin et al., 2014) and B. napus genome sequence (Chalhoub et al., 2014) were published. The reference genomes provided possibilities to explore the genetic variation by GWAS, for that large number of SNPs has to be generated.

DNA analysis has been used in VIR to search the duplicates in the collections, compare of original seeds and reproductions, evaluate biodiversity, variability within landraces, phylogenetic studies, screening collection and breeding material for marker assisted selection (MAS). QTL (Quantitative Trait Locus) analysis and association mapping have been developed.

Large variability within cole landraces has been determined in our investigations using SSR markers, when landraces compassed from 5-8 biotypes, and sometimes distance between biotypes into population is higher than between cultivars.

Morphological study of authenticity of VIR white cabbage collection after more than 10 rounds of reproduction and complicated regeneration procedure showed stability of morphological characters in core collection. Head weight is insignificantly increased during 50-70 years that can be explained by improved selection during reproduction process. Period of vegetation is decreased significantly in two locations; possibly it is connected with climate change. A set of 12 SSRs has been used for comparison of original seeds and the seeds after reproduction. $88 \%$ coincidence between old/original and fresh seeds has been observed that permit to conclude good authenticity of VIR collection.

For QTL analysis a large number of studies - 40-50 articles per year last years - using different types of biparental mapping Brassicaceae populations have being developed to determine genetic control of flowering time, morphological traits from seed to seed, productivity, resistance to clubroot, mosaic virus, downy mildew, biologically active substances, mostly secondary metabolites. The bolting and flowering time is the most important characters in brassicas, but the genetic control of this process is complicated. Co-localized QTLs for different traits, generally for flowering time and plant size were found (Xiao et al., 2014).

For B. oleracea a major genomic region Ef2.1, harboring a robust flowering time QTL containing 29 genes, on chro- mosome 2 was identified using combined a next-generation sequencing-based whole-genome QTL-seq strategy and classical QTL analysis in mapping populations broccoli $\times$ cabbage. Major gene BolGRF6 is a possible candidate gene for early flowering in broccoli line. The identified candidate genomic regions and genes may be useful for molecular breeding (Shu et al., 2018).

In VIR QTL analysis has been developed to identify chromosome loci related to a wide range of phenotypic, morphological, biochemical, immunological traits in $B$. rapa using two DH mapping populations resulted from crosses between leafy, rooted and oilseed lines created in Wageningen University, Netherlands, and B. oleracea using DH mapping population resulted from crosses between broccoli and kailan.

The $B$. rapa populations were evaluated for 47 morphological and phenological traits (bolting and flowering time, growth-related traits, leaf, seed, flower and fruit traits), for biochemical traits (content of protein, ascorbic acid, carotene, chlorophylls) and for resistance to four Xanthomonas campestris pv. campestris Pam. (Dow.) races. 140 QTLs controlling morphological and biochemical traits in DH30 и DH38 B. rapa L. and 10 and 11 co-adaptive blocks of genes correspondingly have been found (Artemyeva et al., 2016). The most important QTLs in both populations were in the bottom of A03, where BrFLC5 that determines flowering time, productivity and biochemical traits is located. The inheritance of broad-spectrum quantitative resistance of $B$. rapa to $X$. campestris pv. campestris has been elucidated and 10 QTLs in DH30 and 19 QTLs in DH38 that control resistance to four races of the pathogen $(1,3,4,5)$ were found (Artemyeva et al., 2018).

In AGDH B. oleracea mapping population QTLs determined plant size traits have been found in the lower part of $\mathrm{C} 01, \mathrm{C} 07$, on the top of C04, C05, C09; QTLs for ascorbic acid content was found in the lower part of $\mathrm{C} 01, \mathrm{C} 03, \mathrm{C} 08$, protein content in the middle of $\mathrm{C} 07$, dry matter and carotenoids content in the lower part of $\mathrm{C} 09$.

Association mapping studies using collections of natural heterogeneous and heterozygous accessions and breeding material are widely developed in Brassicaceae. Pino Del Carpio et al. (2011) studied the secondary metabolite lutein, chlorophylls, carotene variation in $B$. rapa collection from 168 accessions. Wang, Kole (2015) proposed a strategy of combination both QTL and association mapping studies to identify candidate genes explaining trait variation.

Marker-phenotype significant associations in VIR B. rapa core collection of 96 accessions have been found for the same traits as in QTL analysis using 258 SSR and S-SAP molecular markers. Chromosome loci determined bolting time were found on the top of $\mathrm{A} 02$, in the bottom of A03, in the middle of A05 and A06, determined plant weight - in the bottom of A03, A09, in the middle of A05. 11 blocks of co-adapted genes for morphological traits were found; the most important blocks were located on the top of A01, A10, on the top and the bottom of $\mathrm{A} 02$, in the bottom of $\mathrm{A} 03$, in the middle of A05 and A06. The coincidence of positions of chromosome loci determined the same traits by QTL and association mapping on A02, A03, A05 and A06 have been found that judges a rightness of the results. Coincidence of positions of chromosome blocks controlling the biochemical traits on the 
bottom of A03 and in the middle of A05 has been noted too. The most important loci for B. rapa on the top of $\mathrm{A} 02$, on the bottom of $\mathrm{A} 03$, in the higher part of $\mathrm{A} 10$ correspond to genes positions controlling flower time $B r F L C 2, B r F L C 5, B r F L C 1$, that confirms importance of bolting time that determines many morphological and biochemical traits in Brassica plants.

\section{Conclusion}

Screening of brassicas accessions by SSR markers, associated with valuable traits, choosing in QTL analysis and association mapping, confirmed their perspectives for MAS. New VIR cultivars of pak-choi Meggy and VitaVIR, turnip Palitra, included in Russian State Register of Selection Achievements Admitted for Usage available to growing in a territory of Russia, and a lot of breeding material of all brassicas had been created in VIR using MAS.

VIR Brassicaceae collection is an extremely valuable tool for comprehensive fundamental and applied studies.

\section{References}

Artemyeva A.M. Ecological differentiation of Chinese cabbage Brassica rapa ssp. pekinensis (Lour.) Olsson. In: Genetic Collections of Vegetable Crops. St. Petersburg, 2001;148-166. (in Russian)

Artemyeva A.M. Donors and sources for breeding of leafy vegetable Brassica rapa L. crops. In: Catalogue VIR. St. Petersburg, 2004; 740:132. (in Russian)

Artemyeva A.M., Abremskaya S.S. The sources of breeding valuable characters of leafy Brassica rapa L. (Chinese cabbage, pakchoi, tatsoi, zicaitai, mizina, broccoletto). In: Catalogue VIR. St. Petersburg, 2017;850:84. (in Russian)

Artemyeva A.M., Ignatov A.N., Volkova A.I., Kocherina M.N., Konopleva N.V., Chesnokov Y.V. Physiological and genetic components of black rot resistance in double haploid lines of Brassica rapa $\mathrm{L}$. Agricultural Biology (Sel'skokhozyaistvennaya Biologiya). 2018; 53(1):157-169. DOI 10.15389/agrobiology.2018.1.157eng.

Artemyeva A.M., Kocherina N.V., Kurina A.B., Fateev D.A., Chesnokov Y.V. Mapping of economically valuable loci traits in vegetable crops of the Cabbage family (Brassicaceae Burnett). In: Proc. Int. Conf. devoted to the 85th anniversary of the Agrophysical Research Institute "Agrophysical Trends: From Actual Challenges in Arable Farming and Crop Growing Towards Advanced Technologies", St. Petersburg, Sept. 27-29, 2017. St. Petersburg, 2017;231-235. (in Russian)

Artemyeva A.M., Solovjova A.E., Kocherina N.V., Berensen F.A., Rudneva E.N., Chesnokov Yu.V. Mapping of chromosome loci determined manifestation of morphological and biochemical traits of quality in Brassica rapa L. crops. Russ. J. Plant Physiol. 2016; 63(2):259-272. DOI 10.1134/S1021443716020047.

Bradshaw J.E. Root and Tuber Crops (Ser. Handbook of Plant Breeding). N.Y.: Springer-Verlag, 2010. DOI: 10.1007/978-0-387-92765-7.

Chalhoub B., Denoeud F., Liu S., Parkin I.A., Tang H., Wang X., Chiquet J., Belcram H., Tong C., Samans B., Corréa M., Da Silva C., Just J., Falentin C., Koh C.S., Le Clainche I., Bernard M., Bento P., Noel B., Labadie K., Alberti A., Charles M., Arnaud D., Guo H., Daviaud C., Alamery S., Jabbari K., Zhao M., Edger P.P., Chelaifa H., Tack D., Lassalle G., Mestiri I., Schnel N., Le Paslier M.C., Fan G., Renault V., Bayer P.E., Golicz A.A., Manoli S., Lee T.H., Ha Dinh Thi V., Chalabi S., Hu Q., Fan C., Tollenaere R., Lu Y., Battail C., Shen J., Sidebottom C.H.D., Wang X., Canaguier A., Chauveau A., Bérard A., Deniot G., Guan M., Liu Z., Sun F., Lim Y.P., Lyons E., Town C.D., Bancroft I., Wang X., Meng J., Ma J., Pires J.C., King G.J., Brunel D., Delourme R., Renard M., Aury J.M., Adams K.L., Batley J., Snowdon R.J., Tost J., Edwards D., Zhou Y., Hua W., Sharpe A.G., Paterson A.H., Guan C., Wincker P. Early allopolyploid evolution in the post-neolithic Bras- sica napus oilseed genome. Science. 2014;345(6199):950-953. DOI 10.1126/science. 1253435.

Gasich E.L., Khlopunova L.B., Artemyeva A.M., Gannibal F.B., Levitin M.M. Evaluation of Brassica oleracea L. collection on resistance to diseases in North-west region of Russia. In: Phytosanitary Optimization of Agroecosystems. 2013;386-389. (in Russian)

Ghamkhar K., Croser Ja., Aryamanesh N., Campbell M., Kon'kova N., Francis C. Camelina (Camelina sativa (L.) Crantz) as an alternative oilseed: molecular and ecogeographic analyses. Genome. 2010; 53(7):558-567. DOI 10.1139/g10-034.

Gladis T.H., Hammer K. Die Gaterslebener Brassica Kollektion. Feddes Reportium. 1992;103:469-507.

Gómez-Campo C., Prakash S. Origin and domestication. In: GómezCampo C. (Ed.). Biology of Brassica Coenospecies. Amsterdam: Elsevier Press, 1999;33-58. DOI 10.1016/S0168-7972(99)80003-6.

Hanelt P. Cruciferae. Rudolf Mansfelds. Berlin, 1986;272-332.

Liu S., Liu Y., Yang X., Tong C., Edwards D. The Brassica oleracea genome reveals the asymmetrical evolution of polyploid genomes. Nat. Commun. 2014;5:3930. DOI 10.1038/ncomms4930.

Lizgunova T.V. The history of botanical study of Brassica oleracea L. Proceedings on Applied Botany, Genetics and Breeding. 1959; 32(3):37-70. (in Russian)

Lizgunova T.V. The Cabbage. Leningrad, 1965. (in Russian)

Lizgunova T.V. Flora of Cultivated Plants. Vol. 11. Cabbage. 1984. (in Russian)

Methodics on Evaluation and Regeneration of Cabbage Worldwide Collection. Leningrad: VIR Publ., 1988. (in Russian)

Methodics on Evaluation and Regeneration of Rooted Worldwide Collection (Beet, Turnip, Fodder Turnip, Swede). Leningrad: VIR Publ.. 1989;167. (in Russian)

Nagornov S.A., Kornev A.J., Meshcheryakova J.V., Busin I.V., Konkova N.G., Mescheryakov A.G. Biofuel from non-traditional vegetable oils. Nauka v Tsentralnoi Rossii $=$ Science in Central Russia. 2017; 2(26):53-61. (in Russian)

Parkin I.A., Koh C., Tang H., Robinson S.J., Kagale S. Transcriptome and methylome profiling reveals relics of genome dominance in the mesopolyploid Brassica oleracea. Genome Biol. 2014;15(6):R77. DOI 10.1186/gb-2014-15-6-r77.

Pino Del Carpio D., Basnet R.K., De Vos R.C.H., Maliepaard C., Paulo M.J., Bonnema G. Comparative methods for association studies: a case study on metabolite variation in a Brassica rapa core collection. PLoS One. 2011;6(5):e19624. DOI 10.1371/journal.pone. 0019624.

Raiola A., Errico A., Petruk G., Monti D.M., Barone A., Rigano M.M. Bioactive compounds in Brassicaceae vegetables with a role in the prevention of chronic diseases. Molecules. 2018;23:15. DOI 10.3390/molecules23010015.

Romantsova S.V., Gavrilova V.A., Konkova N.G., Pashinin V.A. Composition and spectral characteristics of components of biofuels synthesized from canola oil, false flax and crambe. Vestnik TGU $=$ Bulletin of Tomsk University. 2012;17(1):339-341. (in Russian)

Sainger M., Chaudhary D., Jaiwal P.K., Jaiwal A., Sainger P.A., Jaiwal R. Advances in genetic improvement of camelina sativa for biofuel and industrial bio-products. Renew. Sust. Energ. Rev. 2017; 68:623-637. DOI 10.1016/j.rser.2016.10.023.

Shebalina M.A. Turnip, Fodder Turnip, Rutabaga. Leningrad, 1974. (in Russian)

Shebalina M.A., Sazonova L.V. Root Crops (Brassica - Turnip, Rutabaga, Radish, Small Radish). In: Flora of Cultivated Plants. Vol. 18. Leningrad, 1985;12. (in Russian)

Shu J., Liu Y., Zhang L., Li Z., Fang Z., Yang L., Zhuang M., Zhang Y., $\mathrm{Lu} \mathrm{H}$. QTL-seq for rapid identification of candidate genes for flowering time in broccoli $\times$ cabbage. Theor. Appl. Genet. 2018;131(4): 917-928. DOI 10.1007/s00122-017-3047-5.

Sinskaya E.N. The oleiferous plants and root crops of the family Cruciferae. Proceedings on Applied Botany, Genetics and Breeding. 1928; 19(3). (in Russian) 
Sinskaya E.N. Brassica L. Genera. In: Flora of the USSR. Vol. 8. Moscow; Leningrad, 1939. (in Russian)

Sinskaya E.N. To specification of systematics and phylogeny of fodder, vegetable and oilseed plants of family Cruciferae. Proceedings on Applied Botany, Genetics and Breeding. 1960;33(3):233-250. (in Russian)

Sinskaya E.N. Historical Geography of Cultivated Flora. Leningrad, 1969. (in Russian)

Specht C.E., Diederichsen A. Brassica. In: Hanelt P. (Ed.). Mansfelds Encyclopedia of Agricultural and Horticultural Crops. Vol. 3. Berlin: Springer-Verlag, 2001;3:1435-1465.

Vavilov N.I. The Centers of Origin of Cultivated Plants. Proceedings on Applied Botany, Genetics and Breeding. 1926;2:248. (in Russian)

Wang X., Kole C. (Eds.). The Brassica rapa genome. In: Compendium of Plant Genomes. Springer-Verlag, Berlin, Heidelberg, 2015. DOI 10.1007/978-3-662-47901-8_2.

Wang X., Wang H., Wang J., Sun R., Wu J., Liu S., Bai Y., Mun J.H., Bancroft I., Cheng F., Huang S., Li X., Hua W., Wang J., Wang X., Freeling M., Pires J.C., Paterson A.H., Chalhoub B., Wang B., Hayward A., Sharpe A.G., Park B.S., Weisshaar B., Liu B., Li B., Liu B., Tong C., Song C., Duran C., Peng C., Geng C., Koh C., Lin C., Edwards D., Mu D., Shen D., Soumpourou E., Li F., Fraser F., Conant G., Lassalle G., King G.J., Bonnema G., Tang H., Wang H., Belcram H., Zhou H., Hirakawa H., Abe H., Guo H., Wang H.,
Jin H., Parkin I.A., Batley J., Kim J.S., Just J., Li J., Xu J., Deng J., Kim J.A., Li J., Yu J., Meng J., Wang J., Min J., Poulain J., Wang J., Hatakeyama K., Wu K., Wang L., Fang L., Trick M., Links M.G., Zhao M., Jin M., Ramchiary N., Drou N., Berkman P.J., Cai Q., Huang Q., Li R., Tabata S., Cheng S., Zhang S., Zhang S., Huang S., Sato S., Sun S., Kwon S.J., Choi S.R., Lee T.H., Fan W., Zhao X., Tan X., Xu X., Wang Y., Qiu Y., Yin Y., Li Y., Du Y., Liao Y., Lim Y., Narusaka Y., Wang Y., Wang Z., Li Z., Wang Z., Xiong Z., Zhang Z.; Brassica rapa Genome Sequencing Project Consortium. The genome of the mesopolyploid crop species Brassica rapa. Nat. Genet. 2011; 43:1035-1039. DOI 10.1038/ng.919.

Warwick S.I., Hall J.C. Phylogeny of Brassica and wild relatives. In: Gupta S. (Eds.). Biology and Breeding of Crucifers. New York: CRC Press, 2009;19-36.

Warwick S.I., Mummenhoff K., Sauder C.A., Koch M.A., Al-Shehbaz I.A. Closing the gaps: phylogenetic relationships in the Brassicaceae based on DNA sequence data of nuclear ribosomal ITS region. Plant Syst. Evol. 2010;285:209-232. DOI 10.1007/s00606010-0271-8.

Xiao D., Wang H.G., Basnet R.K., Zhao J.J., Lin K., Hou X., Bonnema G. Genetic dissection of leaf development in Brassica rapa using a "genetical genomics" approach. Plant Physiol. 2014;164: 1309-1325.

\section{ORCID ID}

A.M. Artemyeva orcid.org/0000-0002-6551-5203

A.G. Dubovskaya orcid.org/0000-0003-2487-5912

N.G. Kon'kova orcid.org/0000-0002-4920-3904

Acknowledgements. The work was performed under VIR state assignment "Collection of oil and fiber crops VIR: maintenance, learning, expanding of genetic diversity" (No. 0662-2019-0001), "Genetic resources of vegetable and cucurbit crops from VIR worldwide collection: effective ways of enlarge of biodiversity, discovery of lows of heritable variability, use of adaptive potential" (No. 0662-2019-0003).

Conflict of interest. The authors declare no conflict of interest.

Received April 4, 2019. Revised July 30, 2019. Accepted August 11, 2019. 